FACTA UNIVERSITATIS

Series: Philosophy, Sociology, Psychology and History Vol. 17, Nº 1, 2018, pp. 89 - 95

https://doi.org/10.22190/FUPSPH1801089C

Preliminary Communication

\title{
LIMITS OF SEXUAL FREEDOM AND THE NOTION OF PERVERSION: IS SEXUAL ETHICS “APPLIED”?
}

\author{
UDC 176.4
}

\begin{abstract}
Nenad Cekić
University of Belgrade, Faculty of Philosophy, Department of Philosophy, Serbia
\end{abstract}

\begin{abstract}
This article has two main points: 1) there are no reasons why sexual ethics should be excluded from fashionable "applied ethics" and "bioethics" investigations, and 2) that the key concepts of "sexual discourse" - especially the concept of "perversion" - deserves full philosophical attention. As an example, the author offers a brief analysis of the reasons why, despite the ruling "libertarian paradigm", the concept of "perversion" should be kept in ordinary language.
\end{abstract}

Key words: bioethics, sexual ethics, perversion, ordinary language.

\section{ABOUT THE SUBTITLE}

The subtitle of this article (the question "Is sexual Ethics 'applied'?") is purposefully designed to draw attention to the somewhat problematic status of sexual ethics in contemporary philosophy and theoretical discussion. A similar ambiguity is present in other "applied" branches of ethics, too. For example, nowadays we deal with a range of various "bioethics" that should be a branch of applied ethics. However, philosophical bioethics is, in fact, a tiny part of the current "bioethical" investigations. "Bioethics" today looks like an odd mixture of medicine, politics, jurisprudence, philosophy, psychology, various multidisciplinary "case studies" and, sometimes, even ideology. Essential bioethical problems of euthanasia, abortion, and similar topics are widely discussed by medical staff, lawyers, policymakers and some philosophers. Sometimes the discussion does not present itself as belonging to any particular field of intellectual discourse. ${ }^{1}$

Why is sexual ethics not (still) applied?

Received March 25, 2018 / Accepted May 28, 2018

Corresponding author: Nenad Cekić

University of Belgrade, Faculty of Philosophy, Čika Ljubina 18-20, 11000 Belgrade, Serbia

E-mail: nenad.cekic@gmail.com

${ }^{1}$ Peter Singer's Practical Ethics (Singer 2011) is a classic in this field. On more recent controversies in bioethics see: Liao 2016. and Wiseman 2016. 
Personal sexual morality, which naturally could be a part of bioethics, is not often discussed in bioethical circles. The reasons for that fact may fall into two categories: 1) sexual morality is too practical, and 2) philosophy (mainly ethics) of sex involves issues that are too theoretical to be applied. Let us consider these two provisory theses.

1) For some philosophers, sexual issues were (or still are) not serious enough to be a part of philosophy or even a part of applied ethics. We must keep in mind that all parts of applied ethics, including today's fashionable bioethics, have often been treated as the insignificant, superficial outcome of some more fundamental moral dilemmas. In the course of time, some topics like abortion, euthanasia, infanticide and similar problems have become widely discussed. Finally, bioethics has become a general topic of many variations of public discourse. However, that bioethics is often not ethics (moral philosophy) at all. Furthermore, it seems that issues concerning personal sexual morality are not a subject of contemporary bioethics.

2) There is no sexual ethics. Moral problems related to sexual issues are a part of general morality and a question for normative ethical theory. Problems as problems of the moral status of sexual perversion, sexual fidelity or limits of sexual freedom openly occurred as philosophical issues in the philosophical literature during the 1980's. Sexual ethics in the narrow sense is a philosophy that concerns: a) the meaning and use of general and specific value terms in sexual contexts, and b) the philosophical research of the nature of personal relationships and various decisions in sexual contexts. More than thirty years ago, Roger Scruton in the preface to his Sexual Desire wrote: "The subject of sexual desire has largely been ignored by the modern philosophy (Scruton [1986] 2006, vii)." Today, it is still unclear to what particular area of expertise sexual ethics belongs. The analysis of the phenomenon of human sexual desire is one source of sexual ethics. The second source is the very nature of value-charged terms used in sexual morality, such as "perversion," "adultery," "promiscuity" and the like. On the other hand, medicalrelated moral issues about sex change operations, abortion, and similar problems are not within the scope of sexual ethics in a narrower sense. Some sex-related political and legal matters, such as issues regarding same-sex marriage, are not parts of sexual ethics either. We could be ask what is then left for the sexual ethics in a narrow sense? Some philosophers are willing to say "nothing." There is even some evidence for that kind of claim. Paradoxically, libertarians (broadly speaking), who started the interest in sexual ethics, have already concluded that there is nothing particular about the morality of sex. According to the libertarian thesis, special sexual ethics is a dangerous burden because all problems that constitute the subject of bioethics, allegedly, could be reduced to classical problems of normative ethics such as promise or deception. Even more, it could be potentially dangerous to continue to use classical "sexual" notions such as "perversion." Libertarians claim that those terms "should be discarded."

\section{Libertarians: PeRVERSion, "A CONCEPT Best DisCARDED”}

It is safe to say that the problem of the moral status of perversion obviously belongs to the area of sexual morality. However, we are faced with a very strong demand (due to the fashion or needs of "political correctness") to simply "discard it." Moreover, we can also say that nowadays the "libertarian thesis" is the ruling paradigm in the current literature on sexual ethics. The "discard variation" of basic "libertarian thesis" may be put 
as follows: because of the confusing use of the notion of "sexual perversion" in ordinary discourse, and the difficulties of the analysis of that term, it might be concluded that the very idea of sexual perversion should be discarded altogether. That is, the libertarian proposes that we discard whole (and not unusual) term of ordinary language to avoid its possible abuse.

As Igor Primoratz in his Ethics and Sex has pointed it out, some philosophers have actually proposed just that (Primoratz 1999, 62-65). One was Marquis de Sade. His "sexual libertinism" was an alternative and direct challenge to the traditional view of sex as by nature (and God) ordained to procreation, and legitimate only within marriage: "...There is no extravagance which is not in Nature, none which she does not acknowledge as her own," says de Sade. Therefore "there can exist no evil in obedience to Nature's promptings..." (de Sade 1965, 320-323).

Contemporary philosopher Michael Slote, similarly, argues that the notion of unnatural or perverted behavior, including sexual behavior, is unuseful and should be abandoned. Metaethically, Slote notes that "unnatural" and "perverted" have both descriptive and expressive meaning. The first is almost impossible to capture by a single definition, while the latter is easy to characterize: both words - "unnatural" and "perverted" express horror.

The horror points to the concealed ("real") descriptive meaning of these words in their ordinary use: to call a manner of acting perverted and unnatural is to say that it cannot be found in nature. As most of mainstream "depth" psychology tells us, most of us have some deep, unconscious and repressed impulses towards incest, homosexuality, and possibly some forms of fetishism. For various reasons, we repress such tendencies and keep them unconscious by determining that such behavior is unnatural or perverted: "By calling it "unnatural" [and "perverted"] we think of it as banished to a world other than ours, and this helps to reassure us that the impulse toward such behavior is not in us (Slote 1975, 263)."

Primoratz declines to accept Slote's "inapplicability thesis," but he supports "discard thesis." He argues: "I cannot accept Slote's inapplicability thesis nor, for that matter, de Sade's simplistic naturalism in sexual ethics. But I do think that the idea of unnatural or perverted sex is best discarded. As we have seen, ordinary use is inconsistent and confusing. More importantly, none of the philosophical accounts discussed succeeds in giving the idea a plausible and helpful interpretation. And the philosophical accounts I have discussed cover between them the main lines of argument the subject seems to offer. When we put them aside, the descriptive content of the term amounts to no more than 'unusual sexual preference or behavior.' The term has rich evaluative connotations; but they tend to vary very much, not only in intensity but also in quality. In view of all this, it can safely be said that the term serves no useful purpose. We should therefore simply drop it" (Primoratz 1999, 65).

\section{TWO THESES}

These were summary reviews of the position and propositions of the most prominent advocates of the "discard thesis." Let us now consider the following two theses:

1) If we have a philosophical duty to avoid unnecessary and misleading disputes about sexual morality and sexual ethics, we have to analyze some key value-charged notions in traditional sexual morality. If metaethics shows anything, it is the fact that language cannot be "reformed" by the simple "discarding" of anything. Logical empiricism tried to "discard" the whole language of morality, but that enterprise was nothing but a spectacular 
misfire. Why should we again try something that has been proven impossible? Moreover, it seems like a philosophical duty to show a need for analytical research of language of sex by showing conceptual uncertainties in real and potential uses of the notoriously ambiguous notions such as perversion really is.

2) Conceptual analysis is not everything that we can do in theoretical sexual ethics. However, it seems to be a mandatory starting point. It could clear the path ahead.

As we have just seen, the dominant liberal (or, more accurately, libertarian) paradigm in sexual ethics tells us that the term "perversion" can result in more trouble than benefit. The reason is that perversion is a "Janus term" with two interacting "faces." The term perversion has both a strong evaluative (in this case: negative) component and rather vague descriptive "content." Obviously, it is not the only concept of that kind in that class, but its close relationship with the concept of sexual freedom makes its position central. On the other hand, the term "perversion" in sexual contexts is sometimes used as a synonym for "unnatural." From the libertarian point of view, the potentially ambiguous use of the term with a strong negative emotional charge could even jeopardize the freedom in the extremely sensitive area of sexuality. That is the main reason why "...the concept of sexual perversion is quite unhelpful and is best discarded altogether" (Primoratz 1999, 65).

To cut a long story short: if we keep the notion of perversion in philosophical service we could exploit its emotional charge and interfere with the freedom of sexual choice without any need for (descriptive) justification. In metaethics, that process is well-known as a "persuasive definition" (Stevenson, 1963, 32-54).

Is this argument absolutely correct?

Sexual liberation is a fact and probably an irreversible process. But does it mean that "The True Liberal" must discard all negative connotations in the language of sex?

\section{PRIMA Facie CASES: How to NAME that?}

Any list of sexual perversions is utterly arbitrary. On the other hand, the meaning of the term "perversion" is in perpetual evolution. Let us mention some "traditional" ones: homosexuality, sexual sadism, sexual masochism, exhibitionism, voyeurism, fetishism, transvestism, pedophilia, necrophilia, and zoophilia...Then, the question is: how to determine what is "in" and what is "out"?

We have already used the phrase "negative evaluative meaning" That expression is general enough to cover all kinds of negative reactions to any "perverted" sexual activity: moral condemnation, rage, disgust, outrage, (Michael Slote's?) horror and so on. Nowadays homosexuality and bisexuality are not on the list. However, there are still some practices that at least raise some terminological and/or moral suspicion. We can call those intuitive judgments on some "more-than-unusual practices" - prima facie cases. Those cases are our candidates for the "proper" use of the term "perversion." Let us consider the following cases.

Sadism is still "in" the moral discourse of condemnatory use of "perversion" (that "should be discarded"), but what to do with consensual mutual sadomasochism? Is it a perversion or "unusual sexual behavior"? If the liberal "harm principle" (Mill 1977, 223224 ) is the only basis for the negative attitude towards some old or new sexual practice, what is wrong with possible consensual necrophilia (using someone's body for sexual purposes after his or her death with prior consent obtained)? What is wrong with consensual cannibalism? If we can donate organs or whole bodies for medical purposes, why could we 
not donate whole bodies, or some organs for sexual purposes? What is the moral (or "liberal"?) reason that forbids selling our own body or body parts (post-mortem) to some necrophiliac and cannibalistic society? (It is an almost win-win situation, is it not?) Why is group sex the best-selling product of the porn industry? (Is there anybody to deny this?) We could stop here and say that the term "perversion" is at least partly functional in all these contexts because its evaluative meaning is not limited by any descriptive characteristics of any particular sexual activity.

Now, we have a very clear problem. If we "discard" the notion of perversion, how should we collectively name those practices which are examples of our "prima facie cases"? Some of them are not just "unusual," they are a little more than that. How to name "that" (which we) "should not be doing," without specification? "No-no," maybe?

\section{5. "PERVERSION" IS STILL HERE}

The fact is that some sexual practices have never undergone serious theoretical inquiry. Some are still taboos. For example, the Internet is full of "creampie" and "golden shower" movies. (It is likely that anybody who has owned a permanent e-mail address for twenty years or more could find porn ads that include such activities in their inbox or "junk" folder.) What reason can be given for the condemnation of those practices? There is no "harm," just possible offense, so why anybody makes those "forbidden" movies? Maybe the reason for condemnation could be sheer disgust, like in case of necrophilia and zoophilia? However, those cases are not exactly alike.

Why does nobody speak about objectophilia? It is the fact that internet via the concept of virtual sex brought us just a step away from accepting that sex with the machines and objects is "not very unusual." Moreover, we are just a step away from sexual "interfaces" that would make virtual sexual intercourse touchable. Maybe sex toys were just aids or props. However, imagine a virtual "sex machine" analogous to famous Nozick's experience machine (Nozick 1974, 42). Why should not everybody plug into it?

So, we can just make "an open list" of very and very, very unusual sexual behaviors: sadism, necrophilia, creampie, golden shower, objectophilia...However, the list is not closed - we can continue with coprophagia, for example. This practice is "obviously" very, very unusual. Then, the question is: how to determine the borderline between "very" and "very, very" unusual? Our contention is: by using the term "perversion."

We could add another point. Libertarians are using pretty obsolete metaethical techniques. Of, course, the difference "descriptive/evaluative" is still important. However, contemporary metaethics offers better tools to capture the whole meaning of secondary evaluative terms in some problematic cases, especially in case of "interplay" of descriptive and evaluative meaning. So, the so-called "Cornell realists" offers an idea of "best explanations" (Darwall, Gibbard and Railton 1992, 169-170). To put this idea simply: some term may be treated as descriptive if it can be used in "best explanations." It seems that "perversion" satisfies that condition. Nobody would be surprised if the question "Why he/she do that (e.g., eating human flesh, drinking urine, etc.)" is answered by the simple "explanation": "Because he/she is perverted." There is no need for further explanation. End of story.

To conclude: libertarians are right when they remind us that the term "perversion" due to its powerful value-charge could be abused. Maybe they are right in insisting that the 
"classical" definition of "perversion" should be revised. By "classical," we mean some definition which relies on the natural/unnatural distinction, like Thomas Nagel's "working model" (his doubts included): “...if than there are any sexual perversions, they will have to be sexual desires or practices that are in some sense unnatural, though the explanation natural/unnatural is, of course, the main problem" (Nagel 2009, 256).

Maybe "unnatural" is not the best term to denote "perversion." (Too much inappropriate "connotations" are necessarily involved.) However, let us picture sex vocabulary without the notion of perversion. A "negative" concept of perversion simply warns us that some boundaries in sex must exist. The descriptive meaning of that term could vary, and nothing is unusual about that. We may even say that it should vary because sexual habits are in constant change. However, the very concept of limits in sex has a regulative, not an exact constitutive or even cognitive function. First, any inventory of fundamental notions in any book about sexual ethics includes many so-called "Janus terms" ${ }^{2}$ that are both evaluative and descriptive such as "perversion" or "adultery". The notorious ambiguity of those notions poses the question of what kind of ethics (philosophy) is possible in the area of the sexual relationships. It seems that if there is any philosophy of sex, it should be both essentially theoretical and "doubly applied." It should be a philosophy (at the basic theoretical and the metaethical level), linked to normative ethics (the first level of application), with a particular scope of the research ( the second tier of the application). Furthermore, it appears that multidisciplinarity in sexual ethics is not possible in "bioethics" manner. Moral problems that relate to sexuality are sometimes founded on the deepest moral question as a promise-breaking or deception. Finally, sexual ethics cannot only be reduced to general normative ethics. For example, adultery is not just a promise-breaking practice; the question of the moral status of promiscuity is still open. Also, the notion of perversion, despite libertarian doubts, still looks crucial for our understanding of sex. That notion, with several others, just cannot be "discarded."

Finally, there is some irony (and "defense") in the current practice of using the term perversion in the positive context. Very few people would even be offended if her or his partner would say something like: "MMMM...You are very naughty. I never knew how perverse you are!"

Acknowledgment: This is an article based on two presentations delivered on two international conferences on applied ethics: "Limits of Sexual Freedom and the Notion of Perversion," Sexualities and Freedom, International Network for Sexual Ethics, Ghent, Belgium, 14-16 July 2014; and "Is Sexual Ethics Applied?", Zagreb Applied Ethics Conference 2015, Zagreb, Croatia, 29 June-1 July 2015.

\section{REFERENCES}

Darwall, G., A. Gibbard, \& P. Railton. "Toward fin de siècle Ethics: Some Trends.” Philosophical Review 101 (1992): 115-189.

De Sade, M. The Complete Justine, Philosophy in the Bedroom, and Other Writings. New York, NY: Grove Press, 1965.

Hare, R. M. Essays on the Moral Concepts. London: Macmillan, 1972.

\footnotetext{
${ }^{2}$ Richard Hare calls those terms "secondary evaluative" (Hare 1972, 55-75). In current philosophical use those are "thick" evaluative notions.
} 
Liao, S. M., ed. Moral Brain: The Neuroscience of Morality. Oxford: Oxford University Press, 2016.

Mill J. S. On Liberty. In Collected Works on J. S Mill, edited by J. M. Robson, Vol. 18, 213-310. Toronto \& Buffalo: Toronto University Press, 1977.

Nagel, T. "Sexual Perversion". In Philosophy and Sex, edited by R. B. Baker, and K. J. Wininger, 31-43. Armherst, New York: Prometheus Books, 2009.

Nozick, R. Anarchy, State, and Utopia. Oxford, UK: Blackwell, 1974.

Primoratz, I. Ethics and Sex. Oxford: Routledge, 1999

Scruton, R. Sexual Desire. London: Continuum, [1986] 2006.

Singer, P. Practical Ethics. Cambridge: Cambridge University Press, $3^{\text {rd }}$ Edition, [1980, 1993] 2011.

Slote, M. "Inapplicable Concepts and Sexual Perversion". In Philosophy \& Sex, edited by R. Baker, and F. Elliston, 262-267. Buffalo, NY: Prometheus Books, 1975.

Stevenson, Ch. Facts and Values. New Haven: Yale University Press, 1963.

Wiseman, H. The Myth of the Moral Brain. Cambridge: Cambridge University Press, 2016.

\section{GRANICE SEKSUALNE SLOBODE I POJAM PERVERZIJE: DA LI JE SEKSUALNA ETIKA "PRIMENJENA"?}

Autor ovog članka iznosi dve teze: 1) nema razloga zbog kojih bi "seksualnu etiku” trebalo isključiti iz danas popularne "bioetike"; i 2) da ključni pojmovi seksualne etike, kao što je pojam "perverzije", zaslužuju podrobnu filozofsku analizu. Kao primer potreba za takvom analizom autor iznosi argumentaciju zašto pojam perverzije, uprkos vladajućoj "libertarijanskoj" paradigmi, treba zadržati u upotrebi.

Ključne reči: bioetika, seksualna etika, perverzija, svakodnevni jezik. 